ORIGINAL ARTICLE

\title{
Association of a STAT 6 haplotype with elevated serum $\lg E$ levels in a population based cohort of white adults
}

\author{
S Weidinger, N Klopp, S Wagenpfeil, L Rümmler, M Schedel, M Kabesch, T Schäfer, U Darsow, \\ T Jakob, H Behrendt, H E Wichmann, J Ring, T Illig
}

J Med Genet 2004;41:658-663. doi: 10.1136/jmg.2004.020263

See end of article for authors' affiliations

Correspondence to: Dr S Weidinger, Department of Dermatology and Allergy, Technical University Munich, Biedersteiner St. 29, 80802 Munich, Germany; weidinger@|rz.tum.de

Received 5 March 2004 Revised 9 April 2004 Accepted 13 April 2004
Background: Several studies have shown linkage of chromosome 12q 13-24 with atopy related phenotypes. Among candidate genes in this region is STAT6 (signal transducer and activator of transcription), which is essential for Th2 cell differentiation, recruitment, and effector function.

Methods: We evaluated six polymorphisms of STAT6 for evidence of associations with serum lgE levels and atopic diseases in a population based cross sectional cohort of 1407 German adults. Genotyping was performed using the matrix assisted laser desorption ionisation-time of flight mass spectrometry method. Haplotypes were estimated using the SAS/Genetics module, and population-derived lgE percentiles (50\% $\lg E>53 \mathrm{kU} / \mathrm{l}, 66 \% \lg \mathrm{E}>99 \mathrm{kU} / \mathrm{l}$ and $90 \% \operatorname{lgE}>307 \mathrm{kU} / \mathrm{l})$ were modelled as outcome variables in haplotype trend regression analysis.

Results: All polymorphisms were genotyped successfully. Haplotype reconstruction revealed 8/64 possible haplotypes, reaching estimated frequencies of $1 \%$ or more. One polymorphism in intron 2 (rs324011) showed a significant association with total serum $\lg E(p=0.015)$. A STAT6 risk haplotype for elevated $\lg E$ showing odds ratios of $1.7(p=0.015)$ for $\operatorname{lgE}$ cut-off $100 \mathrm{kU} / \mathrm{l}$, and $1.54(p=0.032), 1.6(p=0.025)$, and 2.54 ( $p=0.007$ ) for lgE percentiles $50 \%, 66 \%$, and $90 \%$, respectively was detected. The increased risk of this haplotype was confirmed by linear haplotype trend regression on log transformed lgE values $(p=0.007)$. Analysis further revealed a risk haplotype for specific sensitisation and a risk haplotype for asthma.

Conclusion: The data indicate that genetic variants within STAT6 contribute significantly to lgE regulation and manifestation of atopic diseases.
A topy is defined as familial tendency to develop characteristic IgE mediated allergic diseases of the skin and airways. ${ }^{1}$ Epidemiological studies have shown a worldwide increase of the prevalence of atopic diseases (atopic eczema, allergic asthma, and rhinoconjunctivitis) over the last few decades, and they currently affect more than $10 \%$ of individuals in Western countries. ${ }^{23}$

The majority of patients with atopic diseases show sensitisation against environmental allergens, with high serum levels of total and allergen specific IgE, and positive skin prick test reactions. ${ }^{4}$ Current pathophysiological concepts suggest interactions between susceptibility genes, the host's environment, and immunological factors. ${ }^{5} \mathrm{~T}$ cells have been shown to be implicated in the pathogenesis of atopic diseases (reviewed by Rogmanani ${ }^{6}$ ), but their exact role is still not fully understood. Although in recent years it has become clear that the Th1/Th2 paradigm is insufficient to describe all immune response patterns associated with the development of atopy (reviewed by El Biaze et $a l^{7}$ ), a critical role for Th2 is is widely accepted. ${ }^{8}$ In addition, at least in the majority of patients, IgE, eosinophils, and factors regulating IgE synthesis and eosinophil numbers and activity (namely Th2 cytokines such as interleukin (IL)-4, -5, -6, -9, - 10, and -13) play a major role in driving atopy pathogenesis. ${ }^{9}$

Genetic susceptibility of IgE responsiveness is likely to be caused by a pattern of polymorphisms in multiple genes regulating immunological responses. ${ }^{10}{ }^{11}$

Family and case-control studies have provided evidence that total serum IgE levels are largely determined by genetic factors that may be independent of specific $\operatorname{IgE}$ responses, and it has been suggested that total serum IgE levels are under stronger genetic control than atopic disease. ${ }^{11-13}$ The production of specific IgE is driven by Th2 cells that secrete IL-4 and-13 in response to antigen presentation. Binding of IL-4 and -13 to the IL-4R alpha chain recruits signal transducer and activator of transcription 6 (STAT6) into the receptor complex, activates germline transcription from the epsilon heavy chain gene locus, and, together with signals derived from the B cell surface molecule CD40, induces isotype switching in B cells and activates genes important for IgE synthesis. ${ }^{14-16}$ Mice lacking STAT6 are unable to undergo class switching to IgE, exhibit an impaired proliferative response to IL4, and cannot differentiate naive T cells into Th2 cells. ${ }^{17}$

More than 10 regions have been identified as candidate regions influencing total serum IgE levels, atopy, and asthma. $^{18}{ }^{19}$ Among the most frequently identified genomic regions is the long arm of chromosome 12 (12q13-24), where STAT6 is located. ${ }^{20}$ Various genome scans and studies restricted to chromosome $12 \mathrm{q}^{21-30}$ have provided evidence for linkage of asthma related phenotypes with chromosome 12 markers. Significant associations with increased serum levels of IgE have been reported for single nucleotide polymorphisms (SNPs) in introns 2,17 , and 18 and for two SNPs in the 3' UTR of the STAT6 gene in a previous family sibling pair study. ${ }^{31}$ However, the primary trait examined within this affected relative study was asthma, and a rather low number of subjects was investigated. We aimed to validate the observations in a large population based cross sectional cohort of 1407 adults and to evaluate STAT6

Abbreviations: IL, interleukin; RAST, radioallergosorbent test; SAP, shrimp alkaline phosphatase; SNP, single nucleotide polymorphism; STAT6, signal transducer and activator of transcription 6; TFB, transcription factor binding 
polymorphisms with regard to associations with atopy related phenotypes.

For our analyses, we chose six polymorphisms spanning the whole STAT6 gene (fig 1). The SNPs were selected on the basis of the above mentioned family study, completely screening all exonic and adjacent intronic regions and the probable promoter region of STAT6. The DNA variants analysed in the present study were the only ones that had been found to be associated with at least one atopic trait. ${ }^{31}$

\section{MATERIALS AND METHODS}

Study population

All subjects were recruited from the MONICA/KORA (Cooperative Health Research in the Augsburg Region) surveys, which are large population based cross sectional studies carried out every 5 years in the city and region of Augsburg, southwest Germany, since 1984. The objective and protocol of the MONICA surveys have been published earlier. $^{32}{ }^{33}$ The study base of the MONICA/KORA surveys consists of all registered residents aged 25-74 years of the city of Augsburg, Germany, and two surrounding counties.

For analysing the influence of STAT6 polymorphisms on IgE levels, we examined the KORA C study group. KORA C is based on a random, cross sectional sample stratified for age and sex studied in 1994/1995 $(\mathrm{n}=4356)$ with a focus on allergic sensitisation and respiratory atopy. In the sera of these subjects, allergen specific IgE antibodies to common aeroallergens (grass and birch pollen, house dust mite, cat, and Cladosporium) were determined by the fluorescence enzyme immunoassay technique (CAP-FEIA; Pharmacia, Uppsala, Sweden). The cutoff point for radioallergosorbent test (RAST) reactivity was set at $0.35 \mathrm{kU} / \mathrm{l}$. For KORA C, we aimed to recruit an enriched sample of 1600 subjects out of the 4178 individuals who had valid RAST results.

Subjects were selected, stratified by age and sex, so as to provide $50 \%$ with and $50 \%$ without a positive RAST, and, furthermore, so that within these groups $50 \%$ had given a positive answer to one of the following questions of the MONICA questionnaire: (a) "Have you had asthma attacks within the last 12 months?", (b) "Do you have allergic rhinitis, e.g., hay fever?", or (c) "How much do you suffer from allergies?" (positive $=$ moderate/severe). To account for an estimated response of $63 \%$, a sample of 2539 subjects was approached. Finally, 1537 subjects participated (60.5\%), of whom $50.2 \%$ exhibited a positive RAST result, and $53.9 \%$ of this group and $43.1 \%$ of those with negative RAST result reported symptoms of atopy. Details of the sampling frame and study design of KORA C are given in fig 2 .

Written and informed consent was obtained from all participants prior to the beginning of the study.

\section{Phenotyping}

All subjects had to complete a standardised questionnaire, which included demographic data and basis allergy questions of the ISAAC survey. ${ }^{34}$ In addition, all probands were interviewed in a standardised manner to report on symptoms of atopic diseases, basic family data, and parental history of atopic diseases. Subjects were also asked to recall their highest level of education.
In all subjects a conventional lancet skin prick test (ALKScherax, Hamburg, Germany), and total and specific IgE measurements (ELISA; CAP-FEIA, Pharmacia, Uppsala, Sweden) were performed using a sample of common allergens (grass, birch, rye, mugwort pollen, Alternaria, Cladosporium, cat, dog, and Dermatophagoides pteronyssinus). Saline and histamine were used as controls. Results showing a positive reaction to saline or no reaction to histamine were excluded from analyses. Subjects were classified as having allergic rhinoconjunctivitis or asthma when they reported a physician's diagnosis of the relevant condition. Specific sensitisation was defined to be present if at least one of the specific IgE antibodies was positive (CAP class $\geqslant 1$, corresponding to $\geqslant 0.35 \mathrm{KU} / \mathrm{l}$ ) or if a positive skin prick test reaction (wheal diameter $\geqslant 3 \mathrm{~mm}$ ) against at least one of the allergens tested was observed.

Based on all subjects with available DNA samples and existing IgE measurements in our dataset $(n=1407)$, IgE percentiles were calculated. Thus, for haplotype analysis, in addition to a cutoff point of $100 \mathrm{kU} / \mathrm{l}$, the 50 th $(53 \mathrm{kU} / \mathrm{l})$, 66th $(99 \mathrm{kU} / \mathrm{l})$ and 90th $(307 \mathrm{kU} / \mathrm{l})$ percentiles for total serum IgE were used as outcome variables.

\section{Genetic analyses}

Genotyping analyses were carried out by using the MassARRAY system (Sequenom, San Diego, USA). Briefly, genomic DNAs were amplified by PCR using HotStarTaq DNA polymerase (Qiagen, Hilden, Germany). Genotyping assays were carried out using $5 \mathrm{ng}$ genomic DNA. PCR primers were used at $167 \mathrm{nM}$ final concentrations for a PCR volume of $6 \mu \mathrm{l}$. The PCR conditions were a hot start at $95^{\circ} \mathrm{C}$ for 15 minutes, followed by denaturing at $95^{\circ} \mathrm{C}$ for 30 seconds, annealing at $56^{\circ} \mathrm{C}$ for 30 seconds, extension at $72^{\circ} \mathrm{C}$ for 1 minute for 45 cycles, and finally incubation at $72^{\circ} \mathrm{C}$ for 10 minutes. PCR products were first treated with shrimp alkaline phosphatase (SAP; Amersham, Freiburg, Germany) for 20 minutes at $37^{\circ} \mathrm{C}$ to remove excess dNTPs and afterwards for 10 minutes at $85^{\circ} \mathrm{C}$ to inactivate SAP. ThermoSequenase (Amersham) was used for the base extension reactions. Extension primers were used at a final concentration of $5.4 \mu \mathrm{M}$ in $10 \mu \mathrm{l}$ reactions. The base extension reaction condition was $94^{\circ} \mathrm{C}$ for $2 \mathrm{~min}$, followed by $94^{\circ} \mathrm{C}$ for 5 seconds, $52^{\circ} \mathrm{C}$ for 5 seconds, and $72^{\circ} \mathrm{C}$ for 5 seconds for 40 cycles. All reactions (PCR amplification, base extension) were carried out in a Tetrad PCR thermal cycler (MJ Research). The final base extension products were treated with SpectroCLEAN resin (Sequenom) to remove salts in the reaction buffer. This step was carried out with a Multimek 96 channel autopipette (Beckman Coulter), and $16 \mu \mathrm{l}$ of resin/water suspension was added into each base extension reaction, making the total volume $26 \mu \mathrm{l}$. After rapid centrifugation (2000 rpm, 3 minutes) in an Eppendorf Centrifuge $5810,10 \mathrm{nl}$ of reaction solution was dispensed onto a 384 format SpectroCHIP (Sequenom) prespotted with a matrix of 3-hydroxypicolinic acid by using a SpectroPoint nanodispenser (Sequenom). A modified Bruker Biflex matrix assisted laser desorption ionisation-time of flight mass spectrometer (Sequenom) was used for data acquisitions from the SpectroCHIP. Genotyping calls were made in real time with MassArray RT software (Sequenom).
Human STAT6 gene

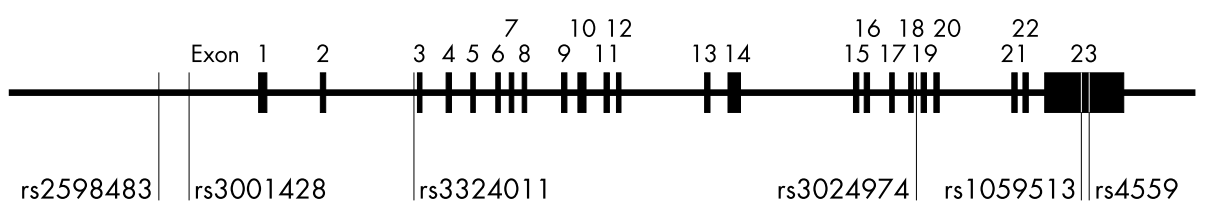

Figure 1 Gene structure of STAT6 showing the location of all SNPs genotyped in this study. 


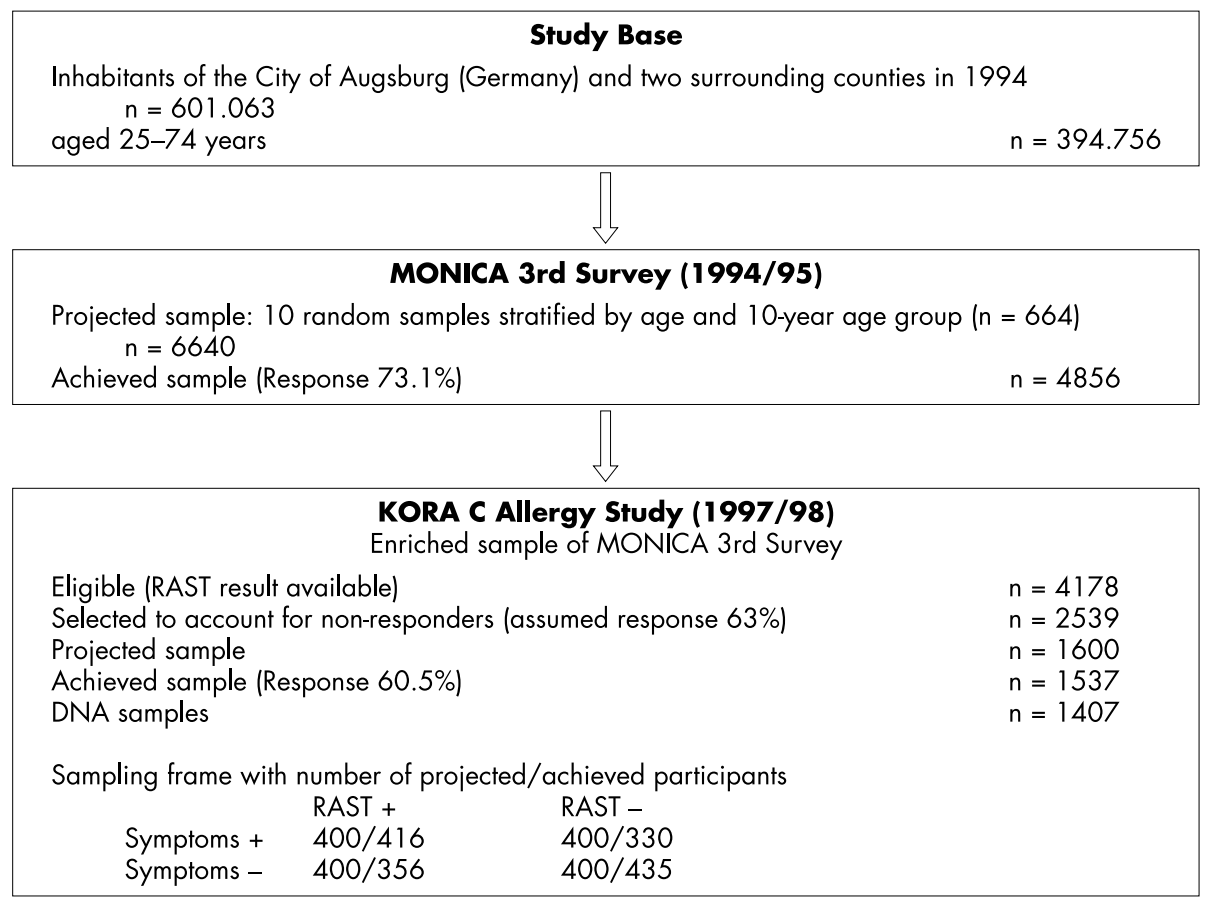

Figure 2 Design and sampling frame of the KORA C study.
For analysis of sequence binding sites MatInspector (release 7.0; Genomatix, Munich, Germany) was used.

\section{Statistics}

Descriptive statistics for quantitative and qualitative values are given by mean (SD) and absolute numbers or frequencies, respectively. For descriptive statistics, SPSS (version 11.5) was used. Association of quantitative traits with SNP genotype was tested with $t$ tests for two independent samples or Satterthwaite tests using the SAS statistical software package (version 8.2). Deviation from Hardy-Weinberg equilibrium was tested with Pearson's $\chi^{2}$ test statistic for any of the SNPs under consideration. Linkage disequilibrium was assessed with procedure ldmax in the Gold software package. Haplotype frequencies were estimated from genotype data using the EM algorithm. ${ }^{35}{ }^{36}$ To evaluate associations with quantitative and qualitative traits, haplotype trend regression models were applied including estimated probabilities of haplotypes in a linear and logistic regression approach as independent variables, ${ }^{37}{ }^{38}$ respectively. Further independent variables were highest school examinations, age, family size, and sex. Because smoking is an essential influence factor on IgE levels and atopic diseases, ${ }^{39} 40$ smoking status was included as independent variable in multiple regressions.

The same covariates were included in logistic regressions testing associations of qualitative traits with SNP genotypes. Results are reported after applying backward elimination and stepwise variable selection. All haplotype analyses were implemented using the SAS/Genetics module. ${ }^{38}$ Odds ratios are given with $95 \%$ confidence intervals (CI) and two sided $\mathrm{p}$ values in parentheses.

\section{RESULTS}

Within the KORA C study individuals $(\mathrm{n}=1537), 8.8 \%$ $(\mathrm{n}=136)$ were diagnosed with asthma, $2.0 \%(\mathrm{n}=30)$ were suffering from atopic eczema, and $25.2 \%(\mathrm{n}=388)$ from allergic rhinoconjunctivitis. IgE serum levels of more than $100 \mathrm{kU} / \mathrm{l}$ were detected in $33.2 \%(\mathrm{n}=510)$. DNA samples were available from 1407 individuals. Between 1285 and 1356 samples (average call rate 95.1\%) were genotyped successfully for the respective STAT6 polymorphisms (fig 1). Allele frequencies and genotyping details are given in table 1. The allele distribution observed in our white population is

Table 1 STAT6 polymorphisms, dbSNP accession number, localisation, allele frequency, call rates, and genotyping primers

\begin{tabular}{|c|c|c|c|c|c|c|c|}
\hline SNP ID* & Location & $\begin{array}{l}\text { Call } \\
\text { rate }\end{array}$ & Allele & $\begin{array}{l}\text { Allele } \\
\text { frequency }\end{array}$ & Direction & PCR primer & Extension primer \\
\hline \multirow[t]{2}{*}{ rs2598483 } & 5'flanking & 95.5 & G & 0.90 & $\mathrm{~F}$ & ACGTTGGATGTACTGTCTGTGGATGTCTGC & CACGTGCTTTGTATGTGCTCC \\
\hline & & & $A$ & 0.10 & R & ACGTTGGATGTGTGCACATACGTGTTCACG & \\
\hline \multirow[t]{2}{*}{ rs3001428 } & 5'flanking & 96.4 & $\mathrm{C}$ & 0.95 & $\mathrm{~F}$ & ACGTTGGATGTGATTTCCAGAACCAGCTCC & CCACACACGTGCACTCATG \\
\hline & & & $\mathrm{T}$ & 0.05 & R & ACGTTGGATGTTCAAACCCTCTGCTGCCTG & \\
\hline \multirow[t]{2}{*}{ rs324011 } & Intron 2 & 91.3 & $\mathrm{C}$ & 0.62 & $\mathrm{~F}$ & ACGTTGGATGGATGCCCCTGGTTTAAGGTG & ATAGCCCTCCTAGGGAC \\
\hline & & & $\mathrm{T}$ & 0.38 & $\mathrm{R}$ & ACGTTGGATGCAGGGACCTCCCATAGATAG & \\
\hline \multirow[t]{2}{*}{ rs3024974 } & Intron 18 & 95.5 & C & 0.89 & $\mathrm{~F}$ & ACGTTGGATGTGACTGACCAAGGGTTGATG & GGGCTTAGTGCTTATCTG \\
\hline & & & $\mathrm{T}$ & 0.11 & $\mathrm{R}$ & ACGTTGGATGAAGGTGAGTGTGGTGGTATG & \\
\hline \multirow[t]{2}{*}{ rs1059513 } & 3'UTR & 96.2 & A & 0.88 & $\mathrm{~F}$ & ACGTTGGATGAATTCCTGTTAGCCAGGTGG & ACGAAGAATCTCAGCCCT \\
\hline & & & G & 0.12 & R & ACGTTGGATGCGTTCACACAGCTATACACG & \\
\hline \multirow[t]{2}{*}{ rs4559 } & 3'UTR & 95.2 & A & 0.63 & $\mathrm{~F}$ & ACGTTGGATGTGAACGTGTATGTACCTAGG & GCAACTAAGGTGCCAGCTATA \\
\hline & & & G & 0.37 & $\mathrm{R}$ & ACGTTGGATGTAGCATATGTCAGAGAGGCC & \\
\hline
\end{tabular}


Table 2 STAT6 haplotypes and haplotype frequencies with $95 \%$ confidence intervals (haplotypes with frequencies $<1 \%$ were not considered)

\begin{tabular}{lllc}
\hline No. & Haplotype & Frequency (\%) & \multicolumn{1}{c}{$95 \% \mathrm{Cl}$} \\
\hline 1 & G-C-T-C-A-A & 37.51 & 35.69 to 39.35 \\
2 & G-C-C-C-A-A & 6.25 & 5.30 to 7.19 \\
3 & A-C-C-C-A-A & 8.93 & 7.83 to 10.03 \\
4 & G-C-C-C-G-A & 9.86 & 8.73 to 10.99 \\
5 & G-C-C-C-A-G & 19.91 & 18.38 to 21.43 \\
6 & G-C-C-T-A-G & 10.36 & 9.17 to 11.54 \\
7 & G-T-C-C-A-G & 4.81 & 4.01 to 5.61 \\
8 & A-C-C-C-A-G & 1.28 & 0.84 to 1.74 \\
\hline \multicolumn{4}{l}{ Cl, confidence interval. } \\
\end{tabular}

consistent with allele frequencies observed in previous studies. ${ }^{29} 31$

Using multiple testing and a two sided significance level of $5 \%$, none of the genotyped polymorphisms showed a significant deviation from Hardy-Weinberg equilibrium.

Of the six SNPs genotyped in KORA C, polymorphism rs324011 showed a significant association with total serum IgE levels with geometric means for serum $\operatorname{IgE}(\mathrm{kU} / \mathrm{l}) 46.4 \mathrm{in}$ CC wildtypes versus 56.6 in CT and TT genotypes $(p=0.015)$.

For haplotype analysis there were 1231 samples available for which genotyping was successful for each of the six STAT6 polymorphisms. The EM algorithm showed 8 of 64 possible haplotypes, exceeding a frequency of $1 \%$. The $95 \%$ CI values for frequencies are small, because of the large study population, indicating sufficiently high accuracy. The main haplotype GCTCAA had a frequency of $37.5 \%$ (table 2). For this haplotype we observed an increased risk of elevated IgE levels for all cutoff points examined, with odds ratios of 1.7 (95\% CI 1.11 to $2.6, \mathrm{p}=0.015), 1.54$ (95\% CI 1.04 to 2.3 , $\mathrm{p}=0.032), 1.6$ (95\% CI 1.06to 2.4, $\mathrm{p}=0.025)$ and 2.5 (95\% CI 1.3 to $5.0, p=0.007)$ for IgE cut-off $(100 \mathrm{kU} / \mathrm{l})$ and $\operatorname{IgE}$ percentiles $50 \%, 66 \%$, and $90 \%$, respectively. The increased risk of this haplotype is displayed in fig 3 and strongly confirmed by linear haplotype trend regression on log transformed $\operatorname{IgE}$ values with same covariates $(p=0.007)$.

Haplotype results are in accordance with the aforementioned association of SNP rs324011 (presence of T allele) with elevated levels of IgE. In particular, the effects of $\mathrm{T}$ allele frequencies of rs324011 on IgE levels with cutoff of $100 \mathrm{kU} / \mathrm{l}$

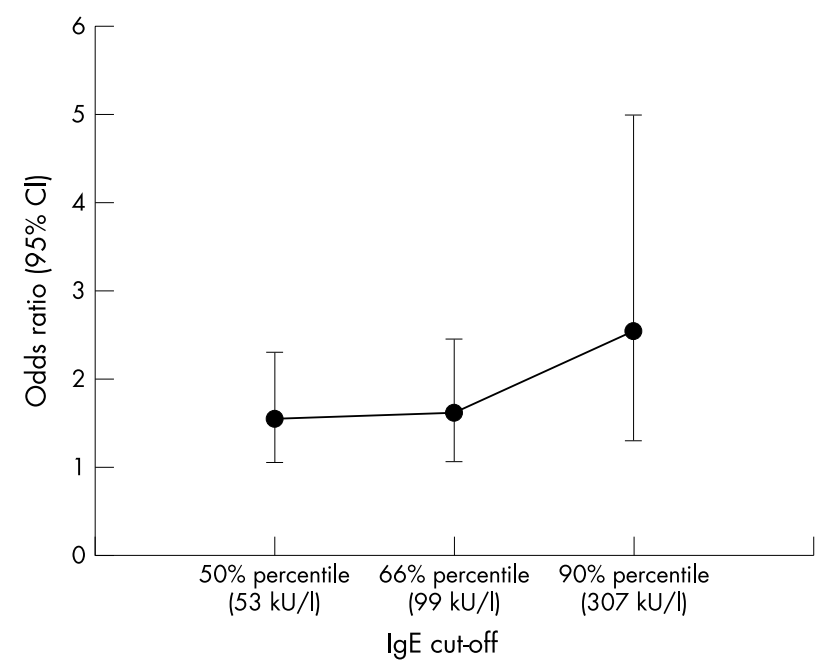

Figure 3 Odds ratios and $95 \%$ confidence intervals for $\lg E 50 \%, 66 \%$, and $90 \%$ percentiles by the STAT6 GCTCAA haplotype. and IgE percentiles $50 \%$ and $90 \%$ in a multiple logistic regression analysis were significantly positive $(p=0.049$, 0.045 and 0.013$)$. This was also confirmed by multiple linear regression on $\log$ transformed $\operatorname{IgE}$ values $(\mathrm{p}=0.016)$.

Analyses further revealed that haplotype GCCTAG is a significant risk factor for the development of specific sensitisation ( $O R=2.0,95 \%$ CI 1.1 to $3.9, p=0.03)$, and haplotype ACCCAG is a significant genetic risk factor for asthma (OR $=2.17,95 \%$ CI 1.8 to $255.5, \mathrm{p}=0.01$ ). Correcting for IgE levels, the haplotype risk factor for asthma remained significant $(\mathrm{p}=0.005)$.

No statistically significant associations were observed between single SNPs or SNP haplotypes in the STAT6 gene and the prevalence of atopic eczema or hay fever (data not shown). In the case of atopic eczema, the lack of association might be due to the low prevalence within the study population.

\section{DISCUSSION}

This study analysed the effects of six polymorphisms in the STAT6 gene on atopic phenotypes by using a population based cohort of 1407 German adults. One single polymorphism (rs324011) revealed to influence total serum IgE levels. Haplotype analysis showed the existence of a high risk STAT6 haplotype for the development of elevated serum IgE levels. Furthermore, one STAT6 haplotype was significantly associated with allergen specific IgE production, and another haplotype was significantly associated with an increased prevalence of asthma. These data indicate that genetic variants in the STAT6 gene affect total and specific serum IgE levels and may thereby be involved in the pathogenesis of atopic diseases.

Although the single polymorphism (rs324011) that revealed significant association with serum IgE levels is not located in the coding regions of the STAT6 gene, it may have functional importance. It is located in intron 2, where two transcription factor binding (TFB) sites for NFKB are found close to each other, suggesting a regulatory function of this region in the transcription of STAT6. It may be speculated that the binding properties of NFKB to the TFB site are altered by the polymorphism. Although STAT6 is known to be the key factor controlling the IgE germline gene promoter, it has been shown that other transcription factors must be present and functional. Importantly, evidence has been provided that NFKB interacts and synergises with STAT6. ${ }^{41} 42$ Thus, the presence of two NFкB sites within the STAT6 sequence may indicate the presence of a feedback regulation between NFкB and STAT6 activation. However, expression analysis and transcription factor binding studies are needed to clarify the role of the polymorphism rs324011 in this putative interaction.

The data from our study are in concordance with a previous report indicating associations of STAT6 polymorphisms with elevated serum IgE in a population of 108 sibling pair families examined for asthma as primary trait. ${ }^{31}$ In our study, the influence of STAT6 polymorphisms and haplotypes on IgE regulation has been examined for the first time in a large population based cross sectional cohort of adults.

It has been suggested that haplotype analyses may be of higher informative value for drawing associations between phenotypes and genetic variation than SNPs.$^{43}$ To assess the effects of haplotypes in our cross sectional study population of unrelated subjects, the 50th, 66th, and 90th percentiles for serum IgE levels were calculated as outcome variables. The 66th percentile corresponded to the widely used arbitrary cutoff of $100 \mathrm{kU} / \mathrm{l}$.

Haplotypes were estimated according to standard methods using the EM algorithm. The frequent STAT6 haplotype combination GCTCAA, which had a prevalence of $37.5 \%$, revealed a strong association with high serum IgE levels. This 
is strongly confirmed by linear haplotype trend regression using log transformed values of observed IgE levels as the quantitative dependent variable.

As the polymorphisms investigated in the present study cover the complete STAT6 gene, it seems unlikely that relevant associations were missed. Linkage disequilibrium decreases even within the gene. Associations with elevated serum IgE clearly focus on rs324011. Haplotype GCTCAA is the only one with a $\mathrm{T}$ allele at position rs324011 (table 2). Thus the strongest contribution to the haplotype effect observed in this analysis for total IgE was made by the polymorphism rs324011, which was also significant in the single analysis. However, although rs324011 is significantly associated with serum IgE levels and is a good candidate for a functional SNP as it alters a TFB site, it is also possible that it is only in linkage diseqilibrium with the causal variant(s).

We further observed that haplotype GCCTAG is a significant risk factor for the development of specific sensitisation, and the haplotypic combination ACCCAG is a risk factor for asthma. However, asthma was not the primary trait examined within this study, and the number of individuals suffering from asthma was low $(\mathrm{n}=136)$. In addition, no associations between STAT6 SNPs or haplotypes and asthma were detected in a previous family based association study focusing on asthma. ${ }^{31}$ In contrast, a strong association of a SNP within the 3'UTR of STAT6 with mild atopic asthma characterised by presence of specific IgE or high total IgE was reported in a Japanese population of adults. ${ }^{44}$ Furthermore, most of the positive linkage results to $12 \mathrm{q} 13-24$ have been reported for asthma and only to a minor extent for IgE levels. Thus, further studies with sufficient numbers of cases are needed to clarify the role of STAT6 as an asthma candidate locus on 12q.

In conclusion, our data indicate that STAT6 gene polymorphisms and haplotypic combinations significantly contribute to the regulation of total serum IgE levels, which have been shown to be under strong genetic control in segregation analysis. One polymorphism located in intron 2 of the STAT6 gene seems to be mainly responsible for the observed association results. Owing to its localisation in the centre of a NFKB transcription factor binding site, this polymorphism may exert a functional role. In addition, STAT6 polymorphisms possibly also influence specific IgE production and manifestation of atopic diseases such as asthma.

\section{ACKNOWLEDGEMENTS}

This work was founded by the German Ministry of Education and Research (BMBF)/ National Genome Research Network (NGFN) research grants NGFN UWS15T03 (a) and (b). Genotyping was performed in the Genome Analysis Center (GAC) of the GSF. The computational assistance of $\mathrm{H}$ Baurecht, Institute for Medical Statistics and Epidemiology, Technical University Munich, Germany, and G Fischer, Institute of Epidemiology, GSF-National Research Center for Environment and Health, Neuherberg, Germany, is gratefully acknowledged. We also thank R Holle and M Wulff, GSF-National Research Center for Environment and Health, Neuherberg, Germany, for their assistance in data management.

\section{Authors' affiliations \\ S Weidinger, L Rümmler, U Darsow, T Jakob, J Ring, Department of Dermatology and Allergy Biederstein, Technical University Munich, Germany \\ N Klopp, H E Wichmann, T Illig, Institute of Epidemiology, GSF- National Research Center for Environment and Health, Neuherberg, Germany \\ S Wagenpfeil, Institute for Medical Statistics and Epidemiology, Technical University Munich, Germany \\ M Schedel, M Kabesch, University Childrens' Hospital, Ludwig Maximilians University Munich, Germany \\ T Schäfer, Institute of Social Medicine, Medical University Lübeck, Germany}

S Weidinger, T Jakob, H Behrendt, J Ring, Division of Environmental Dermatology and Allergy GSF/TUM, GSF National Research Center for Environment and Health \& ZAUM Center for Allergy and Environment, Technical University Munich, Germany

Conflicts of interest: none declared

\section{REFERENCES}

1 Ring J, Kramer U, Darsow U, Behrendt $\mathrm{H}$. Why are allergies increasing? Curr Opin Immunol 2001;13:701-8

2 Burney PGJ. Epidemiologic trends. In: Barnes PJ, Grunstein MM, Leff AR, Woolcock AJ, eds. Asthma. Philadelphia: Lippincot-Raven Publishers, 1997.

3 The International Study of Asthma and Allergies in Childhood (ISAAC) Steering Committee. Worldwide variation in prevalence of symptoms of asthma, allergic rhinoconjunctivitis, and atopic eczema: ISAAC. Lancet 1998;351:1225-32.

4 Werfel T, Kapp A. Environmental and other major provocation factors in atopic dermatitis. Allergy 1998;53:731-9.

5 Leung DYM, Bieber T. Atopic dermatitis. Lancet 2003;361:151-60.

6 Romagnani S. The role of lymphocytes in allergic disease. J Allergy Clin Immunol 2000; 105:399-408.

7 El Biaze M, Boniface S, Koscher V, Mamessier E, Dupuy P, Milhe F, Ramadour $M$, Vervloet $D$, Magnan $A$. T cell activation, from atopy to asthma: more a paradox than a paradigm. Allergy 2003;58:844-53.

8 Kay AB. Allergy and allergic diseases. Second of two parts. N Engl J Med 2001;344:109-13.

9 Novak N, Bieber T. Allergic and nonallergic forms of atopic diseases. J Allergy Clin Immunol 2003;112:252-62.

10 Xu J, Postma DS, Howard TD, Koppelman GH, Zheng SL, Stine OC, Bleecker ER, Meyers DA. Major genes regulating total serum immunoglobulin E levels in families with asthma. Am J Hum Genet 2000;67:1 163-73.

11 Bazaral M, Orgel HA, Hamburger RN. Genetics of IgE and allergy: serum IgE levels in twins. J Allergy Clin Immunol 1974;54:288-304.

12 Palmer LJ, Burton PR, Faux JA, James AL, Musk AW, Cookson WO. Independent inheritance of serum immunoglobulin $\mathrm{E}$ concentrations and airway responsiveness. Am J Respir Crit Care Med 2000;161:1836-43.

13 Lebowitz MD, Barbee R, Burrows B. Family concordance of $\lg \mathrm{E}$, atopy, and disease. J Allergy Clin Immunol 1984;73:259-64.

14 Kelly-Welch AE, Hanson EM, Boothby MR, Keegan AD. Interleukin-4 and interleukin-13 signaling connections maps. Science 2003;300:1527-8.

15 Bacharier LB, Geha RS. Molecular mechanisms of lgE regulation. J Allergy Clin Immunol 2000; 105:S547-58.

16 Kaplan MH, Wurster AL, Smiley ST, Grusby MJ. Stat6-dependent and -independent pathways for IL-4 production. J Immunol 1999;163:6536-40.

17 Shimoda K, van Deursen J, Sangster MY, Sarawar SR, Carson RT, Tripp RA, Chu C, Quelle FW, Nosaka T, Vignali DA, Doherty PC, Grosveld G, Paul WE, Ihle JN. Lack of IL-4-induced Th2 response and lgE class switching in mice with disrupted Stat6 gene. Nature 1996;380:630-3.

18 Collaborative Study on the Genetics of Asthma. A genome-wide search for asthma susceptibility loci in ethnically diverse population. Nat Genet 1997;15:389-92

19 Daniels SE, Bhattacharrya S, James A, Leaves NI, Young A, Hill MR, Faux JA, Ryan GF, le Souef PN, Lathrop GM, Musk AW, Cookson WO. A genome wide search for quantitative trait loci underlying asthma. Nat Genet 1996;383:247-50.

20 Moffatt MF, Cookson WO. Linkage and candidate gene studies in asthma. Am J Respir Crit Care Med 1997; 156:S1 10-12.

21 Wist $M$, Fischer $G$, Immervoll $T$, Jung $M$, Saar $K$, Rueschendorf $F$, Reis $A$ Ulbrecht M, Gomolka M, Weiss EH, Jaeger L, Nickel R, Richter K, Kjellman NI, Griese $M$, von Berg A, Gappa M, Riedel F, Boehle M, van Koningsbruggen S, Schoberth P, Szczepanski R, Dorsch W, Silbermann M, Wichmann HE, the German Asthma Genetics Group. A genome-wide search for linkage to asthma. German Asthma Genetics Group. Genomics 1999;58:1-8.

22 Ober C, Tsalenko A, Parry R, Cox NJ. A second-generation genomewide screen for asthma-susceptibility alleles in a founder population. Am J Hum Genet 2000;67:1154-62.

23 Yokouchi Y, Nukaga Y, Shibasaki M, Noguchi E, Kimura K, Ito S, Nishihara M, Yamakawa-Kobayashi K, Takeda K, Imoto N, Ichikawa K, Matsui A, Hamaguchi H, Arinami T. Significant evidence for linkage of mitesensitive childhood asthma to chromosome $5 q 31-q 33$ near the interleukin 12 B locus by a genome-wide search in Japanese families. Genomics 2000;66:152-60.

24 Dizier MH, Besse-Schmittler C, Guilloud-Bataille M, Annesi-Maesano I, Boussaha M, Bousquet J, Charpin D, Degioanni A, Gormand F, Grimfeld A, Hochez J, Hyne G, Lockhart A, Luillier-Lacombe M, Matran R, Meunier F, Neukirch F, Pacheco Y, Parent V, Paty E, Pin I, Pison C, Scheinmann P, Thobie N, Vervloet D, Kauffmann F, Feingold J, Lathrop M, Demenais F. Genome screen for asthma and related phenotypes in the French EGEA study. Am J Respir Crit Care Med 2000;162:1812-18.

25 CSGA. A genome-wide search for asthma susceptibility loci in ethnically diverse populations. The Collaborative Study on the Genetics of Asthma (CSGA). Nat Genet 1997;15:389-92.

26 Haagerup A, Bjerke T, Schiotz PO, Binderup HG, Dahl R, Kruse TA. Asthma and atopy-a total genome scan for susceptibility genes. Allergy 2002:57:680-6.

27 Barnes KC, Neely JD, Duffy DL, Freidhoff LR, Breazeale DR, Schou C, Naidu RP, Levett PN, Renault B, Kucherlapati R, lozzino S, Ehrlich E, Beaty TH, Marsh DG. Linkage of asthma and total serum IgE concentration to markers on 
chromosome 12q: evidence from Afro-Caribbean and Caucasian populations. Genomics 1996;37:41-50.

28 Nickel R, Wahn U, Hizawa N, Maestri N, Duffy DL, Barnes KC, Beyer K, Forster J, Bergmann R, Zepp F, Wahn V, Marsh DG. Evidence for linkage of chromosome 12q15-q24.1 markers to high total serum lgE concentrations in children of the German Multicenter Allergy Study. Genomics 1997;46:159-62.

29 Immervoll T, Loesgen S, Dutsch G, Gohlke H, Herbon N, Klugbauer S, Dempfle A, Bickeboller H, Becker-Follmann J, Ruschendorf F, Saar K, Reis A, Wichmann $\mathrm{HE}$, Wist $M$. Fine mapping and single nucleotide polymorphism association results of candidate genes for asthma and related phenotypes. Hum Mutat 2000; 18:327-36.

30 Wilkinson J, Grimley S, Collins A, Thomas NS, Holgate ST, Morton N. Linkage of asthma to markers on chromosome 12 in a sample of 240 families using quantitative phenotype scores. Genomics 1998:53:251-9.

31 Duetsch G, Illig T, Loesgen S, Rohde K, Klopp N, Herbon N, Gohlke H, Altmueller J, Wjst M. STAT6 as an asthma candidate gene: polymorphismscreening, association and haplotype analysis in a Caucasian sib-pair study Hum Mol Genet 2002;11:613-21.

32 Bothig S. WHO MONICA Project: objectives and design. Int J Epidemiol 1989; 18:S29-37.

33 Keil U, Liese AD, Hense HW, Filipiak B, Doring A, Stieber J, Lowel H. Classical risk factors and their impact on incident non-fatal and fatal myocardial infarction and all-cause mortality in southern Germany. Results from the MONICA Augsburg cohort study 1984-1992. Monitoring Trends and Determinants in Cardiovascular Diseases. Eur Heart J 1998;19:1 197-1207.

34 Asher MI, Keil U, Anderson HR, Beasley R, Crane J, Martinez F, Mitchell EA, Pearce N, Sibbald B, Stewart AW, Strachan D, Weiland SK, Williams HC. International Study of Asthma and Allergies in Childhood (ISAAC): rationale and methods. Eur Respir J 1995;8:483-91.

35 Excoffier L, Slatkin M. Maximum-likelihood estimation of molecular haplotype frequencies in a diploid population. Mol Biol Evol 1995;12:921-7.
36 Slatkin $M$, Excoffier L. Testing for linkage disequilibrium in genotypic data using the Expectation-Maximization algorithm. Heredity 1996;76:377-83

37 Zaykin DV, Westfall PH, Young SS, Karnoub MA, Wagner MJ, Ehm MG. Testing association of statistically inferred haplotypes with discrete and continuous traits in samples of unrelated individuals. Human Heredity 2002;53:79-91.

38 SAS II. SAS/Genetics ${ }^{\circledR}$ User's Guide. USA: Cary, NC, 2002.

39 Wuthrich B, Schindler C, Medici TC, Zellweger JP, Leuenberger P. IgE levels, atopy markers and hay fever in relation to age, sex and smoking status in a normal adult Swiss population. SAPALDIA Team. Int Arch Allergy Immunol 1996; 111:396-402.

40 Jarvis D, Chinn S, Luczynska C, Burney P. The association of smoking with sensitivity to common allergens: results from the European Community Respiratory Health Survey. J Allergy Clin Immunol 1999;104:934-40.

41 Shen CH, Stavnezer J. Interaction of Stat6 and NF-kappaB: direct association and synergistic activation of interleukin-4-induced transcription. Mol Cell Biol 1998; 18:3395-404

42 Stütz AM, Woisetschlager M. Functional synergism of STAT6 with either NFkappa B or PU.1 to mediate IL-4-induced activation of IgE germline gene transcription. J Immunol 1999; 163:4383-91.

43 Stephens JC, Schneider JA, Tanguay DA, Choi J, Acharya T, Stanley SE, Jiang R, Messer CJ, Chew A, Han JH, Duan J, Carr JL, Lee MS, Koshy B, Kumar AM, Zhang G, Newell WR, Windemuth A, Xu C, Kallbfleisch TS, Shaner SL, Arnold K, Schulz V, Drysdale CM, Nandabalan K, Judson RS Ruano G, Vovis GF. Haplotype variation and linkage disequilibrium in 313 human genes. Science $2001 ; 293: 489-93$.

44 Gao PS, Mao XQ, Roberts MH, Arinobu Y, Akaiwa M, Enomoto T, Dake Y, Kawai M, Sasaki S, Hamasaki N, Izuhara K, Shirakawa T, Hopkin JM. Variants of STAT6 (signal transducer and activator of transcription 6) in atopic asthma. J Med Genet 2000;37:380-2. 